\title{
Local subcutaneous atrophy after occipital nerve block
}

\author{
Oksipital sinir blokajı sonrası gelişen lokal subkutanöz atrofi
}

\section{(1) Samet Sancar KAYA, ${ }^{1}$ (D) Ferhat BALGETiR ${ }^{2}$}

To the Editor,

Local corticosteroid injections are commonly used to reduce inflammation and pain in joints, ligaments, tendons and other soft tissues. In addition, nerve blockade with corticosteroids (CS) has an important role in the treatment of headache. Nerve blocks made by combination of local anesthetic and CS reduce inflammation, inhibiting nerve compaction, reducing the amount of nociceptive chemical mediators and suppressing abnormal electrical activity in damaged nerves. ${ }^{[1]}$

A 15-year-old male patient underwent right occipitalis major nerve blockade (12.86 mg Betamethasone dipropionate $+5.26 \mathrm{mg}$ Betamethasone sodium phosphate $+10 \mathrm{mg}$ lidocaine $\mathrm{HCl}$ ) for cluster-type headache. One month after the injection, the patient was admitted with a complaint of pitting in the area where the injection was made. The patient underwent injection of anatomical alopecia and a $3 \mathrm{~cm}$ diameter circular full-thickness soft tissue atrophy. Full-thickness atrophy of scalp was observed in cranial computed tomography and no pathology was observed in adjacent bone cortex.

Local CS injections can have many side effects such as infection, bleeding, flushing, hypersensitivity reactions, tendon ruptures, hypopigmentation and soft tissue atrophy. The risk of soft tissue atrophy is less than 1\%.[ It usually develops within 1-4 months after injection and recovers within a year. Surgical treatments such as fat tissue injection or grafting can be considered as atrophy longer than one year. ${ }^{[3]}$
While all CS injections can cause soft tissue atrophy, fluorogenic CS are more likely to cause soft tissue atrophy due to their stable, low-resolution, and longacting effects. For this reason, such as triamcinolone hexacetonide and triamcinolone acetonide, which are long-acting and low-resolution CS, are more suitable for use in large joints and deep structures such as the knees, shoulders and elbows. It is suggested that betamethasone sodium and dexamethasone with higher resolution be used in more superficial structures such as bursa, tendon sheath, metacarpophalangeal joint, interphalangeal joint and carpal tunnel.

The place where the nervus occipitalis major block is applied is the neighborhood where the trapezius and semispinalis capitis muscles attach to the occiput. These muscles and aponeuros, as well as fat tissue may go into atrophy by injecting high doses of long-acting storage steroids.

Although side effects of CS injections are rare, patients should be informed about these side effects.

\section{References}

1. Portenoy RK, Foley KM, Inturrisi CE. The nature of opioid responsiveness and its implications for neuropathic pain: new hypotheses derived from studies of opioid infusions. Pain 1990;43(3):273-86.

2. Papadopoulos PJ, Edison JD. The Clinical Picture - Soft tissue atrophy after corticosteroid injection. Cleve Clin J Med 2009;76(6):373-4.

3. Imagawa K, Ohkuma S. A case of fat injection for treating subcutaneous atrophy caused by local administration of corticosteroid. Tokai J Exp Clin Med 2010;35(2):66-9.

\footnotetext{
'Department of Physical Medicine and Rehabilitation, Patnos State Hospital, Ağrı, Turkey ${ }^{2}$ Department of Neurology, Fırat University Faculty of Medicine, Elazığ, Turkey

Submitted: 12.01.2018 Accepted after revision: 11.09.2018 Available online date: 13.12.2018

Correspondence: Dr. Samet Sancar Kaya. Patnos Devlet Hastanesi, Fiziksel Tıp ve Rehabilitasyon Kliniği, Ağrı, Turkey. Phone: +90 - 505 - 7536059 e-mail: sametsancarkaya@hotmail.com

(c) 2019 Turkish Society of Algology
} 